\title{
Model of Predicting Bidding Costs for Construction Projects in Nigeria using Public Procurement Act 2007
}

\author{
Mohammed Lawal Yahaya ${ }^{1}$ \\ ${ }^{1}$ Department of Physical Planning and Development, \\ Usmanu Danfodiyo University, \\ Sokoto \\ Isma'il Umar' \\ ${ }^{2}$ Department of Quantity Surveying, \\ Hussaini Adamu Federal Polytechnic, \\ Kazaure, Jigawa
}

\author{
A. J Babalola ${ }^{3}$ \\ ${ }^{3}$ Department of Quantity Surveying, \\ Faculty of Environmental Science, \\ University of Lagos \\ Mohammed Sani ${ }^{4}$ \\ ${ }^{4}$ Department of Building, \\ Faculty of Environmental Science, \\ Abubakar Tafawa Balewa University, Bauchi
}

nation (Bayliss, 2004). Such impacts were identified in education, manufacturing, Agriculture, Telecommunication, real estate transaction among other (Dalrymple, Lionel \& Warren, 2006; Adinyira, Fugar \& Osei, 2011; Tominiy et al., 2015).

These are largely achieved through ensuring adequate procurement processes by all public sector organization in a country. Public procurement is the process whereby public sector organizations acquire goods, services and works from third parties (Pavel, 2009; Reimarova, 2011; Sarfo \& Mintah, 2013). It also includes money spent by public sector to provide key services directly or indirectly to citizens in areas such as welfare, education, social care and health. Such services are delivered through procurement mechanisms with a formal competitive process.

Effective public procurement is essential for good public service and governance. The public sector in the United Kingdom (UK) for example spends over $£ 150$ billion a year on the goods and services necessary to deliver public services (European Commission, 2007). Public sector organizations are expected to apply the highest professional standards when spending money on behalf of taxpayers to ensure they get a good deal and to provide appropriate and necessary goods and services to the quality required meeting user needs (Sarfo, \& Mintah, 2013).

However, Federal contractors, service providers (FCSP), and researchers (Onyema, 2011; Jibrin et al., 2015) identified some problems and organizational weaknesses inherent in the Nigerian procurement system (Public Procurement Act 2007). These include the bidding costs (transaction costs) incurred with participation in the tender processes by contractors, non- availability of trained procurement officer, less compliance with the Act by many government organizations, lengthy period of procurement processes before award (Dadzie, 2015; Omagobon, 2016; Shwarka \& Anigbogu, 2012).

This paper investigates magnitudes of bidding costs incurred by contracting firms when tendering for construction projects in North-West Nigeria. The study explores these firms' expenses at the post bidding stage. 
The objectives of this paper are: (1) to find explanatory variables (Procurement Act 2007 Sections) that significantly influence the bidding costs of a contracting firms' in the study area and (2) to construct and test models to predict the magnitudes of costs incurred by contracting firms, based on the procurement Law in Nigeria.

\section{LITERATURE REVIEW}

\section{Construction Firms}

The construction industry is one of the key players of any economy. The sector has the potentials to grow further due to economic development, industrialization, urbanization, information technology and relationship across displine (Gupta, 2009; Hosseini, Chileshe, Zuo, \& Baroudi 2012; Ibrahim, Riy, Ahmed \& Imtiaz, 2016). The industry contributed to the GDP of about 7 to $10 \%$ based on research evidence (Winch, 1996; Voordijk, 2000).

The industry comprises of organizations and persons who includes companies, firms and individuals working as consultants, main contractors and sub-contractors, material and component producers etc. operation or activities such as civil engineering works, infrastructural provision, housing, maintenance and repairs, residential and commercial building are the main activities were carried out. Government, individuals, privates and nongovernmental organizations are the purchasers (Clients), financier, regulators and operators in the sector (Tanzania Ministry of works, 2003). It has been argued that the public sector organization is the major client of the sector among all those patronize it National Bureau of Statistics (NBS Report, 2015).

\section{The public procurement Act 2007 (PPA 2007)}

Since independence of Nigeria in 1960 , the country has been experiencing a high degree of mismanagement of resources particularly in the area of public procurement. There have been existing open abuses to rules and standards in the award and execution of public contracts in Nigeria. These were evident in over-invoicing, inflation of contract costs, and proliferation of white-elephant projects and diversion of public funds through all kinds of manipulation of contract system.

The regulatory bodies that were set up to ensure compliance with laid down rules and regulations on procurement and award of contracts in the public sector appeared ineffective.

This resulted in a high level of corruption and enormous wastage of public resources, lack of transparency, accountability, fairness and openness. The situation made foreign and even local investors to lose confidence in the Nigerian economy. It must be noted that the prevailing high level of corruption was closely linked up with the public sector procurement systems, and considering that about ten percent of the gross domestic product (GDP) must pass through the procurement systems. It then became imperative that the public procurement systems must be reformed if Nigeria must achieve economic growth and developmental strides in this new millennium (Fayomi, 2013).
It was in the light of the above that President Olusegun Obasanjo on assumption of office, in 1999, sought for and obtained the World Bank assistance to undertake a study of the existing procurement and financial systems in Nigeria. The outcome was the proposal submitted by the World Bank to Mr. President in 1999 that was tagged the "Country Procurement Assessment Report" (CPAR) which indicated the need for reform of the procurement law based on the United Nations Commission on International Trade Law (UNCITRAL) which has proven effective in a number of countries in the developed world, even in Lithuania, Estonia and Tanzania. The findings of the Study (CPAR), which covered institutional as well as organizational structures relating to the existing procurement regime (Yahaya, Oyediran \& Onukwube, 2019a; Fayomi, 2013).

\section{Bidding/Tendering Cost}

There are two concepts of bidding in the construction industry ( Aje et al., 2016): competitive and noncompetitive bidding practice (Johnstone, Bedard and Ettredge, 2004). Shash (1993) argues that a construction company can either negotiate with the client or use a competitive bidding process to obtain a job. In the case of competitive bidding as a default method in the PPA 2007 , openness in the process of selection becomes the underlying factor. As the name implies, it must also be competitive and transparent. In Nigeria today, traditional method of construction is commonly used (Oladinrin, Olatunji and Hamza, 2013). This procurement system allows flexible application of competitive bidding in construction process as contained in Part IV section (16)(6) (a)-(g), partV section (17-23)(e) and part VI section(2433)(1)-(4) of the Act 2007. Documents such as company tax, pension, industrial training fund, national social insurance and methods of securing them are to be considered by the bidder in any public projects under the federal government (Yahaya, Oyediran \& Onukwube, $2019 b$ ). These are part of the determinant factors to be considered for a contractor or supplier to win such projects. Oyeyipo, Odusami, Ojelabi and Afolabi (2016) opined that other factors have to be considered by contractors apart from the client requirement for survival, particularly in today's competitive bidding. The different bidding situations together with the decision involved in the conversion of the estimate into a tender bid is often considered to be the most important step in the bidding process (Oyeyipo et al., 2016).

They further stated that factors such as reputation, performance, technical competence and managerial capabilities should be considered by contractors in competitive bidding. This will increase and guaranteeing their chances of winning bids in the market. To this list of bidding costs Rajeh (2014) added contract administration, information, enforcement and procurement system. From these studies, this research chose three bidding costs variables to ascertain magnitude of bidding construction projects by contracting firms (see Table 1) on the basis of minimizing overlaps among the bidding costs determinant. These were used as the dependent variables of this study. 
Table 1: Bidding/Tendering Sources of Transaction Costs

\begin{tabular}{|c|c|c|c|}
\hline Measures & Label & Description & Measurement Level \\
\hline Eligibility Documents & $\mathrm{ED}_{1}$ & $\begin{array}{l}\text { Various types of documents } \\
\text { required at the bidding process } \\
\text { with it related transaction cost } \\
\text { associated with it }\end{array}$ & $\begin{array}{l}1=\text { one-off costs, } 2=\text { contract sum, } 3=\text { company } \\
\text { share, } 4=\text { Annual turnover, } 5=\text { Arbitrary. }\end{array}$ \\
\hline Contract Administration & $\mathrm{CA}_{2}$ & $\begin{array}{l}\text { Component of transaction costs } \\
\text { attached with the pre-bidding } \\
\text { administration by the } \\
\text { contracting firms }\end{array}$ & $\begin{array}{l}1=\text { very high, } 2=\text { high, } 3=\text { minimum, } 4=\text { very } \\
\text { minimum and } 1=\text { weekly, } 2=\text { every two weeks, } \\
3=\text { monthly, } 4=\text { others }\end{array}$ \\
\hline Securing related document & $\mathrm{SRD}_{3}$ & $\begin{array}{l}\text { Processes adopted in securing } \\
\text { the various documents with it } \\
\text { associated costs by contracting } \\
\text { firms }\end{array}$ & Same as in $\mathrm{CA}_{2}$ above \\
\hline Construction projects & $\mathrm{BCC}_{4}$ & $\begin{array}{l}\text { Type of construction projects } \\
\text { bids in the last three ( } 3 \text { ) years by } \\
\text { contracting firms }\end{array}$ & $\begin{array}{l}\text { 1= Housing, } 2=\text { Residential, } 3=\text { Commercial, } 4= \\
\text { Non-Residential } 5=\text { Infrastructure projects }\end{array}$ \\
\hline
\end{tabular}

\section{Procurement Laws affecting Bidding Costs}

After defining bidding costs measures (Table 1), the next level is to review procurement sections that influence bidding costs in construction projects. The federal governments through the legislatives enact a law called the PPA 2007 under the supervision of the Bureau of public procurement to make sure that all federal government parastatal complied with the PPA 2007 in all their procurement activities for a fiscal year. The PPA 2007 has its guide to how bidding/tendering will be conducted both by the contractors/suppliers and client.

This study adopted the PPA 2007 parts IV-VI and the various section under them. The PPA parts considered are: (Fundamental Principal of Procurement- Part IV Section 16 subsection (6)(a)-(d), 2. Organization of ProcurementsPart V Sections 17 - 23 (3) Procurement Methods- Goods and Services- Part VI Section $24-38$. These sections were used as the independent variables of this study.

\section{Cost of bidding documents}

The next factor which plays a role in influencing of transaction cost is the costs of financial bids document. In the event of a lesser amount for financial documents, transaction costs during the technical and financial bidding phases will be relatively low, but it is likely that total number of bidders will be higher due to a strong competitive bidding process. One would expect the public-sector cost of bidding to increase with less number of bidders.

This is due to more work for the public agency in terms of pre screening, and technical bids evaluations, and also due to the increase in the transaction cost of losing bidders. Figure 2 below outlines the transaction costs as a percentage of capital cost with respect to the costs of bids documents in the tendering phase.

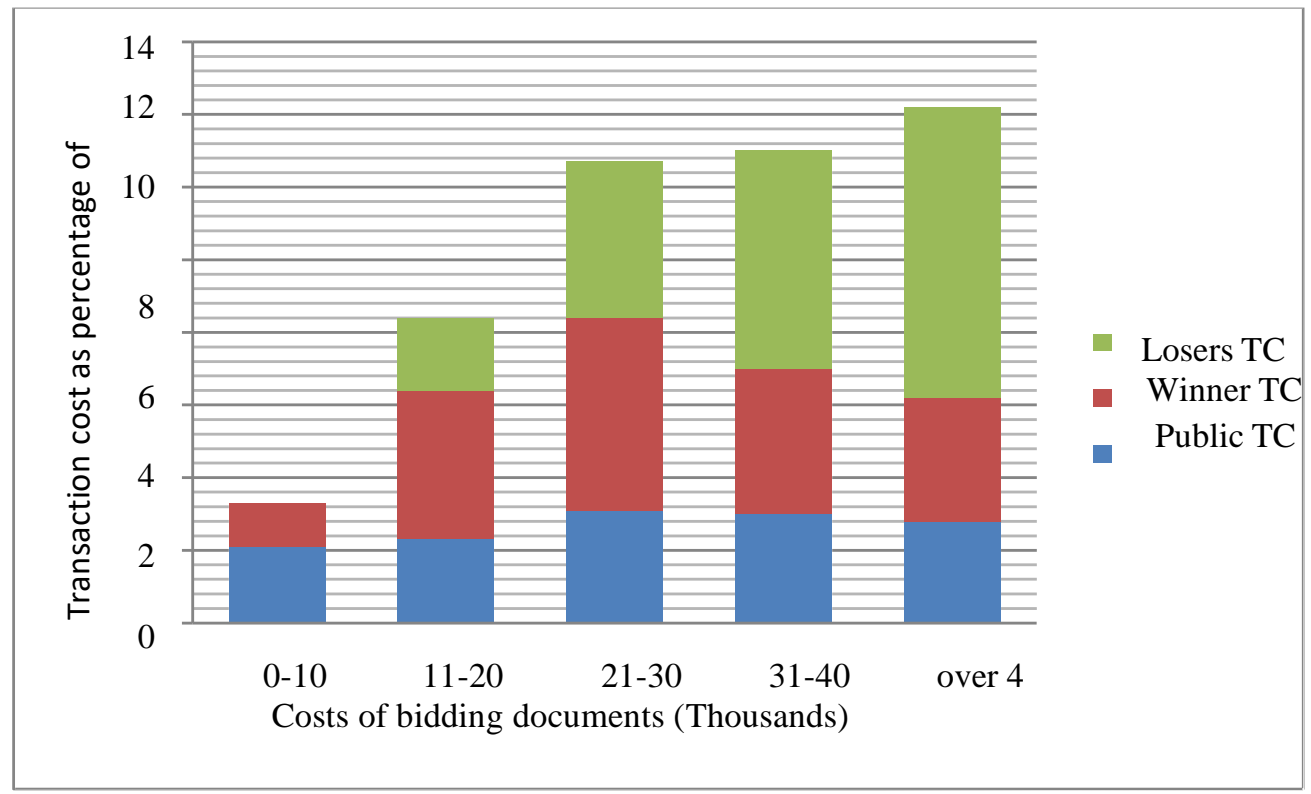

Figure 2: Construction Project transaction cost based on financial bids documents costs. Source: (Dudkin \& Välilä,2005) 


\section{Statement of the Research Problem and Knowledge Gap}

Several studies have recognized the presence and magnitude of transaction expenses incurred by contracting company. For instance, Whittington (2008) finds in separate studies that pre-contract transaction costs in the design-bid-build method range from 0.4 to 8.8 per cent (average 2.6 per cent) of the contract value. Design and build project method 0-5.7 per cent (average 2.2 per cent) of the complete project estimate. According to Dudkin and Valila (2005), on average about 2-3 per cent of the complete contract amount was incurred as transaction costs during the pre-contract stage of infrastructure projects.

But, these studies evaluated transaction costs magnitude (TCM) based on variables such as: contract enforcement, tracking, administration, negotiation, dispute resolution, project management effectiveness, transaction environment and stakeholder attitudes. This results offer some first insight into the problem, therefore, it is important to recognise what they do not do. They have not stated the magnitude of the traditional public procurement of construction projects bidding with regards to developing countries (e.g Nigeria) in terms of their transaction costs magnitude (TCM) incurred.

Therefore, the review of the previous studies on transaction costs magnitude impact on contractors has indicated a vacuum of research based-knowledge. That can be fill through identify the magnitude of transaction costs incurred by contractors in terms of their bidding requirements and process in Nigeria. The predicament of this study, therefore, is to develop model that can predict the transaction costs magnitude of contractors in construction project procurement in public sector, and sources of such transaction costs within the PPA 2007.

In this study, it is hypothesized from $\mathrm{H}_{1}-\mathrm{H}_{7}$ could be used to predict transaction costs magnitude.

H1: Public Procurement Act has a significant influence on Eligibility Documents in bidding

$\mathbf{H}_{2}$ : Eligibility Documents has a significant influence on Transaction costs incurred in bidding construction projects

H3: Public Procurement Act has a significant influence on Contract Administration in bidding

H4: Contract Administration has a significant influence on Transaction costs incurred in bidding construction projects

H5: Public Procurement Act has a significant influence on Securing Related Documents in bidding

H6: Securing Related Document has a significant influence on Transaction costs incurred in bidding construction projects

H7: Public Procurement Act has a significant influence on Transaction costs incurred in bidding construction projects.

Figure 3 shows the typical hypothesized conceptual framework based on partial least squares-structural equation modelling (PLS-SEM).

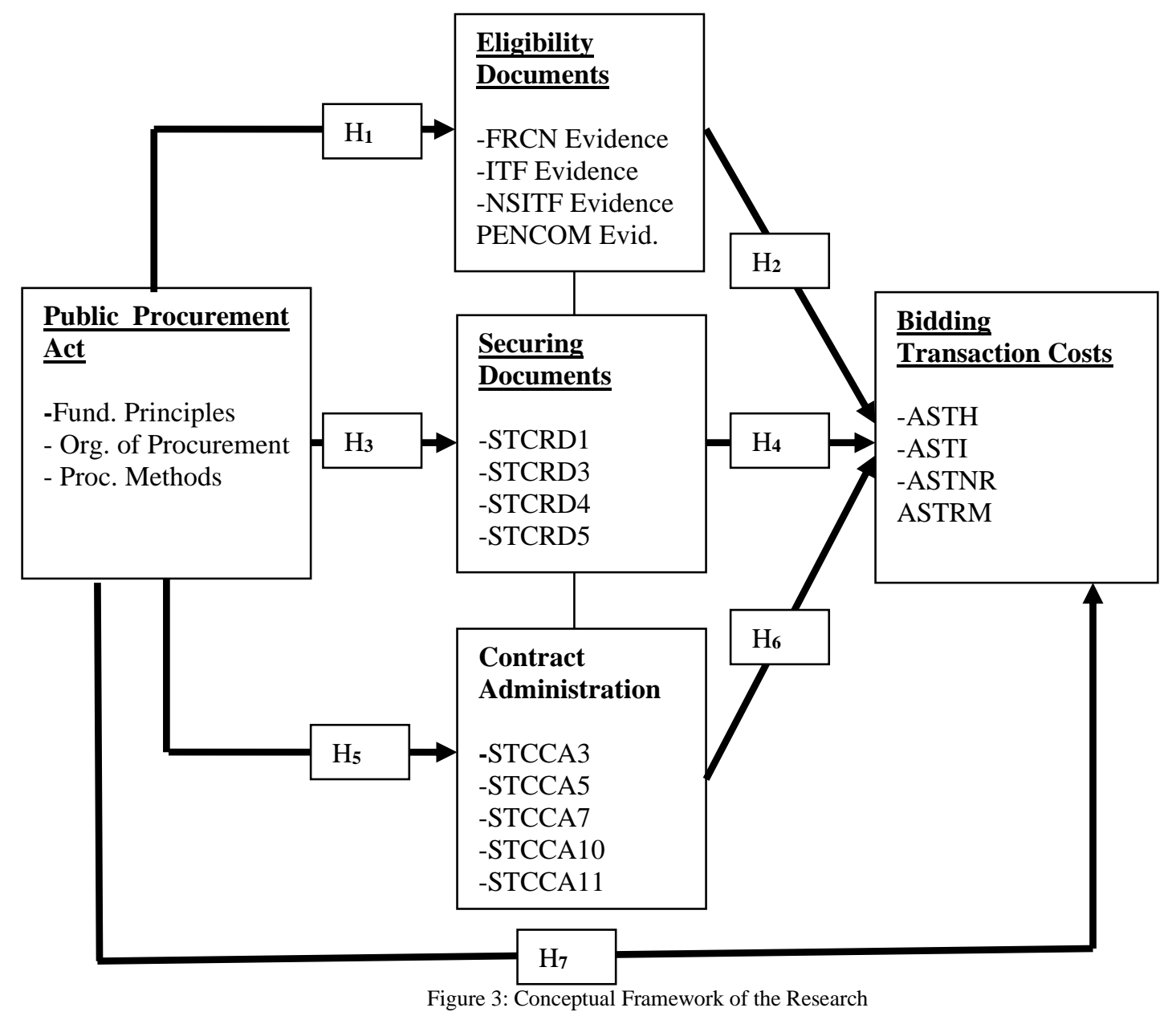




\section{The Conceptual Framework Operationalization}

The Conceptual Framework for this study was drawn from the combination of the framework reviewed in the literature. The theory underpinning this conceptual framework was based on the economic theory of transaction costs.

The theory means that there were expenses linked to the search for the appropriate prices, the negotiation, contracting and the conclusion of agreements. In fact, market members must pay the cost of those items which are not part of the agreement to be concluded. This conceptual framework evaluated public procurement Act 2007 (PPA 2007) on the basis of the fundamental principles, organisation of procurement and method of procurement in the PPA 2007 and Transaction costs sources, addressing eligibility documents, contract administration and securing related documents costs.

It assesses the bidding transaction costs in construction as (average successful tender in Housing, Infrastructure, Nonresidential building and repairs and maintenance buildings).

This study has one (1) independent variable, three (3) intervening variables and one (1) dependent variable. Procurement guides is the independent variable while eligibility document, contract administration and securing related document serve as the intervening variables between procurement Act and bidding transaction costs in construction. Bidding transaction costs in construction serves as the dependent variable.

\section{RESEARCH METHODOLOGY}

\section{Research Approach}

This study adopted quantitative method with data from questionnaire administration. This quantitative research viewed the world as made-up of observable and measurable facts, emphasing positivist paradigm. It tried to group problems into measurable categories which can be generalised on the entire subject (Golafshani, 2003). In addition, quantitative research provided opportunity to researchers to master the problem under investigation and generate testable hypothesis.

\section{Research Design}

However, this study adopted non-experimental research design also known as survey research design. Survey research strategy comprises of process of collecting data such as questionnaire and interview. Survey method refers to complete set of techniques used to carry out a survey research, collect and manage data (Lynn, Erens \& Sturgis, 2012). Survey research approach was adopted in this study because research questions consisted of 'what' question where raised.

The strength of survey approach for this study was identified from the research question used and the degree of focus on contemporary as opposed to historical event (Yi, 2013). Therefore, it comprised of population and sample design, data collection mode, instrument administration and collection, data coding and imputation, weighting and analyses.

\section{Research Population}

The population for this study comprises construction firms that executed federal government projects in the study area (North-west geopolitical zone).

The population frame consists of 143 construction firms that carried out different category of works and goods from North-West State respectively.

\section{Sampling Frame, Techniques and Size}

The sample unit for this study is construction firms while the sample elements are Directors/CEOs and project managers in the organisations. The sample frame consists of all registered contractors on the national database of Bureau of Public Procurement (BPP) that are classified and categorized in the first batch exercise by BPP of 143 .

The study employed a stratified simple random sampling technique in drawing the sample size. This is achieved by dividing the population of 143 by the number of stratum (states in the North-West geopolitical zones). Samples within each state in the stratum (construction firms) where drawn (Creswell, 2017). Each construction firm has common characteristics or identification means, in which other does not have such as, the contractors ID and Interim registration report ID. The sample size of 143 was used based on census methods.

\section{METHOD OF DATA ANALYSIS}

\section{Partial Least Squares-Structural Equation Modelling (PLS-SEM)}

Partial least squares structural equation modelling (PLSSEM) is a variance based second generation multivariate statistical tool used in establishing structural relationship between exogenous latent constructs and endogenous latent constructs. In order to establish the relationship between the research constructs and to test the hypotheses of the research, the partial least squares structural equation modelling is employed. In using PLS-SEM, two stage evaluation criteria are used.

The first stage is the assessment of the measurement model to establish if the manifest items are measuring the underlying construct they supposed to measure. The second stage is the evaluation of the structural model which assess the interrelationships between the research constructs in the model (Ramayah, Lee, \& In, 2011).

Evaluation of the measurement model entails assessing the individual item reliability, the internal consistency of the models through Cronbach's alpha and composite reliability, convergent validity and discriminant validity (Hair, Sarstedt, Ringle, \& Mena, 2012; Memon \& Rahman, 2013; Wong, 2013).

The structural model is assessed by evaluating the individual path coefficients, the coefficient of determination $\left(\mathrm{R}^{2}\right)$, the effect size $\left(\mathrm{f}^{2}\right)$, the predictive relevance $\left(\mathrm{Q}^{2}\right)$ and the Goodness-of-Fit $(\mathrm{GoF})$ of the model (Hair, Sarstedt, Hopkins, \& Kuppelwieser, 2014; Lowry \& Gaskin, 2014). 


\section{RESULTS AND DISCUSSION}

\section{Assessment of Measurement Model}

The first stage in PLS-SEM evaluation is the assessment of the measurement model to ensure that the manifest (indicators or factor loadings) variables are measuring the underlying constructs they are meant to measure.
As a rule of thumb, Hair et al. (2007) provide a guideline to interpret the factor loading, where factor loadings with value of \pm .50 or greater are considered very significant; a loading of \pm 40 is considered most important; a loading of \pm .30 is considered significant (Osman \& Muhammad, 2017). In this study, Table 2 and Figure 5 it can be seen that the factor loadings of all observed variables or items are adequate, ranging from 0.542 to 0.939 .

Table 2: Factor Loadings for Construct

\begin{tabular}{lllc}
\hline Construct & Code & Item & Factor Loadings \\
\hline Eligibility Documents & FRCN_CERT & Financial regulation council of Nigeria Certificate & 0.727 \\
& ITF_CERT & Industrial training fund Certificate & 0.837 \\
& NSITF & National social insurance trust fund & 0.753 \\
& PENCOM & Pension contribution Certificate & 0.925 \\
\hline \multirow{2}{*}{ Contract Administration } & STCCA3 & Time it takes to negotiate & 0.788 \\
& STCCA5 & Interest rate on loan for projects & 0.704 \\
& STCCA7 & Cost incurred annually in bidding & 0.923 \\
& STCCA10 & Average amount spent in a year & 0.580 \\
& STCCA11 & Average No. of public projects bid in a year & 0.538 \\
\hline Securing & STCRD1 & Method used in obtaining documents & 0.586 \\
Documents & STCRD3 & Time it takes to obtain the documents & 0.568 \\
& STCRD4 & Process of obtaining the documents & 0.834 \\
& STCRD5 & Sources of information on bidding & 0.647 \\
\hline Procurement Act & PGA & Selection of in appropriate procurement method & 0.631 \\
& PGB & Certificate of No Objection process & 0.686 \\
& PGC & Lowest responsive bidder experience & 0.565 \\
& PGE & Complaint of non-award of contract & 0.714 \\
\hline Bidding transaction Costs & ASTH & Average successful tender in housing & 0.910 \\
& ASTI & Av. successful tender in infrastructure & 0.696 \\
& ASTNR & Av. Successful tender in non-Residential & 0.811 \\
& ASTRM & Av. Successful tender in repairs\& Maint. & 0.551 \\
\hline
\end{tabular}

The factor loadings of latent variables as in Table 2 to observed variables where above .50 for all construct (Hair et al., 2006). This suggests that the items correlated significantly to the factor itself and evidence of indicator reliability.

\section{Reliability and Validity of the Measurement Model}

Table 3: Internal Consistency Reliability and Convergent validity Test

\begin{tabular}{lccc}
\hline Paths & Cronbach's Alpha & Composite Reliability & $\begin{array}{c}\text { Average Variance Extracted } \\
\text { (AVE) }\end{array}$ \\
\hline Contract Admin & $\mathbf{0 . 7 0 1 5}$ & $\mathbf{0 . 8 1 8}$ & $\mathbf{0 . 6 8 5}$ \\
Eligibility Documents & $\mathbf{0 . 8 3 2}$ & $\mathbf{0 . 8 8 8}$ & $\mathbf{0 . 6 6 7}$ \\
Procurement Act & $\mathbf{0 . 7 1}$ & $\mathbf{0 . 7 6 5}$ & $\mathbf{0 . 7 9 8}$ \\
Securing related document & $\mathbf{0 . 7 2 2}$ & $\mathbf{0 . 7 9 6}$ & $\mathbf{0 . 7 8 9}$ \\
Bidding Transaction Costs & $\mathbf{0 . 7 6 4}$ & $\mathbf{0 . 8 1 9}$ & $\mathbf{0 . 7 3 8}$ \\
\hline
\end{tabular}

After confirming the factor loadings for the indicators or manifest variable, the study tested the constructs for validity as discussed in the previous sections. Two tests were employed: convergent validity and discriminant validity. To test the convergent validity, Average variance extracted (AVE) from each item on a construct is measured whose value should be 0.5 or higher (Barclay, Thompson \& Higgins (1995) and Fornell \& Lacker (1981).

Table 3 shows that the values of AVE test of all constructs range from 0.667 to 0.798 which are above the recommended value of .50 .

\section{Discriminant Validity test}

Table 4: Discriminant Validity Using Fornell and Larcker Criteria

\begin{tabular}{lrrrrrr}
\hline Paths & CA & ED & PG & SRD & BTCC \\
\hline Contract Administration (CA) & & $\mathbf{0 . 8 2 8}$ & & & & \\
Eligibility Documents (ED) & & -0.326 & $\mathbf{0 . 8 1 7}$ & & & \\
Procurement Guide (PG) & & 0.571 & -0.533 & $\mathbf{0 . 8 9 3}$ & \\
Securing Related Documents (SRD) & & 0.514 & -0.442 & 0.543 & $\mathbf{0 . 8 8 8}$ & \\
Bidding Transaction Costs (BTCC) & & -0.115 & 0.441 & -0.130 & -0.223 & $\mathbf{0 . 8 5 9}$ \\
\hline
\end{tabular}


For discriminant validity to be upheld, it has been suggested that the Average Variance Extracted (AVE) should be greater than .50 in order to justify using a construct (Barclay et al., 1995). All the AVE values for each construct (figures in bold in Table 4) is above the recommended value of .50 .

Furthermore, the discriminant validity is checked by considering the latent variable correlation with square root of the AVE, which needs to be transferred to the diagonals in correlation table as shown in Table 4. The values that are bold in the diagonal must be higher than all other values in the row. According to Fornell \& Larcker (1981a), the AVE should be greater than the squared correlation to achieve discriminant validity.

Moreover, it can also be observed that the square root of the AVE for a given construct is greater than the absolute values of the standardized correlation square of the given construct in the analysis. Thus, discriminant validity is supported, indicating that all constructs used in this study are different from each other (Osman \& Muhammad, 2017).

\section{ASSESSMENT OF STRUCTURAL MODEL}

\section{Assessment of path coefficients}

Hypothesized relationships in the PLS-SEM are evaluated by examining the structural model's path coefficients. The path coefficients show the relative importance or influence of the exogenous constructs on endogenous construct. They range from -1 to +1 . The closer the coefficient is to -1 or +1 the stronger the relationship while closeness to zero signifies weak relationship (Hair et al., 2014b; Memon \& Rahman, 2013).

For better quality of the structural model, the path coefficients are required to be significant. The significant is determined through re-sampling procedure called bootstrapping.

The path coefficients of the research structural model are presented in Figure 5 and Table 5 below.

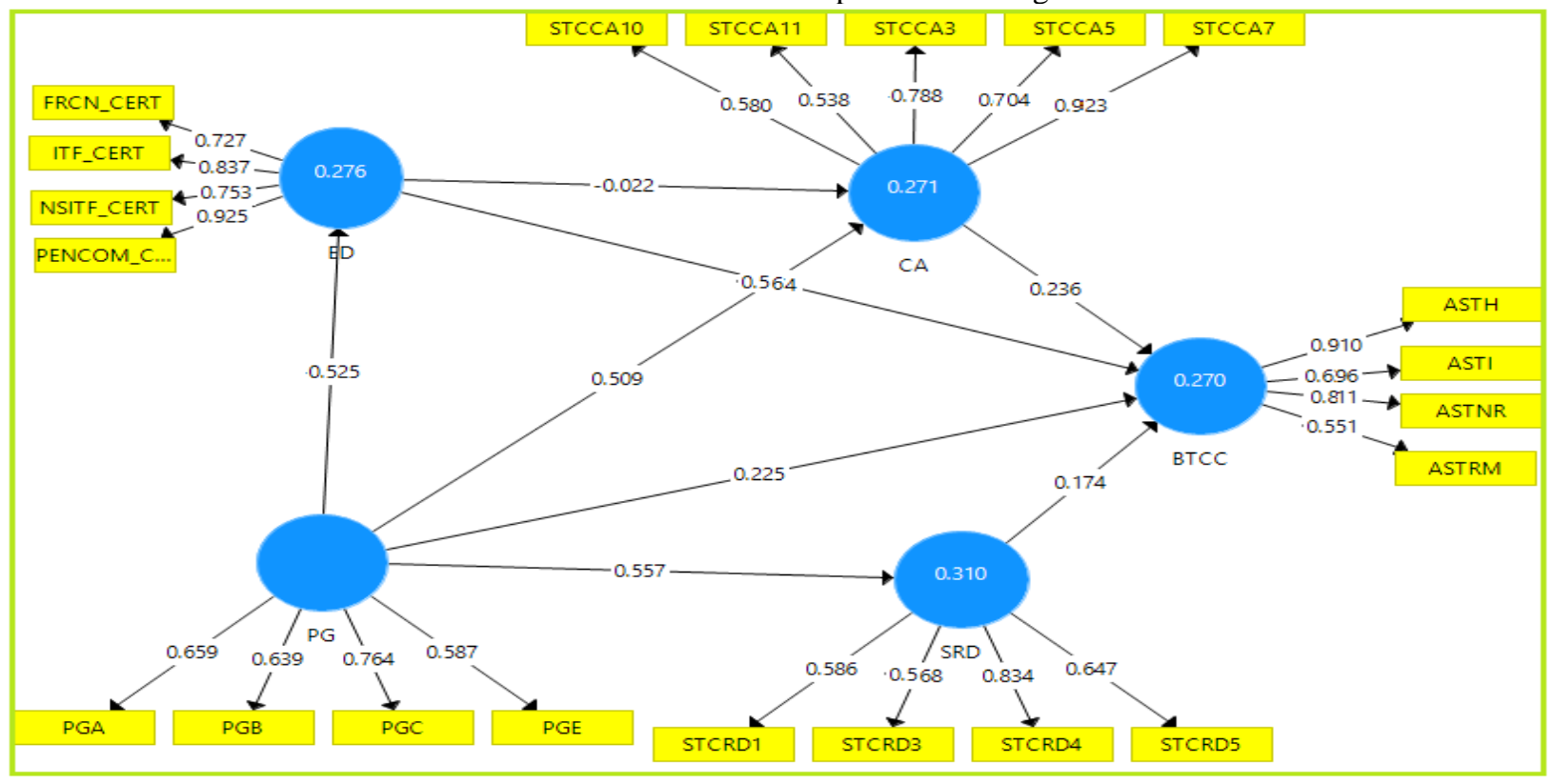

Figure 5 First iteration transaction costs of bidding structural model

The hypothesized model in this study Figure 5 has four direct hypotheses: (1) eligibility documents to bidding transaction costs, (2) procurement guide to bidding transaction costs, (3) contract administration to bidding transaction costs, (4) securing related documents to bidding transaction costs.

\section{HYPOTHESIS TEST}

Null Hypothesis (Ho): The source of transaction costs does not predict the costs of bidding for construction projects in North-West Nigeria.

The path coefficient in PLS-SEM is similar to the regression analysis and standardized beta coefficient $(\beta)$ (Henseler, Ringle \& Sinkovic, 2009). The significance of the hypothesis is tested by calculating the t_ value of every path on the model $\beta$-value, as shown in Figure $5 . \mathrm{H}_{1}$ hypothesized that public procurement Act significantly influence the costs of eligibility document in the bidding transaction costs for construction (BTCC).
The findings in Table 5 and Figure 5 confirms the significant relationships $(\beta=0.489 ; \mathrm{T}=6.096 ; \mathrm{p}<0.0 .05)$. Therefore, $\mathrm{H}_{1}$ is supported. That the eligibility documents costs has significantly contributed to the transaction costs of contractors' bidding were hypothesized in $\mathrm{H}_{2}$.

The result substantiates the hypothesis $(\beta=-0.449, \mathrm{~T}=$ 6.151, $\mathrm{p}=0.005)$. Public Procurement Act $\mathrm{H}_{3}$ was also predicted to influence the costs of contract administration CA $\mathrm{H}_{3}(\beta=0.521 ; \mathrm{T}=2.579, \mathrm{p}<0.005)$, hence, $\mathrm{H}_{3}$ is supported. $\mathrm{H}_{4}$ was stated the contract administration will influence the bidding transaction costs for construction $(\beta=$ $0.243 ; \mathrm{T}=1.976, \mathrm{p}<0.005)$, therefore, $\mathrm{H}_{4}$ was robustly supported in the study.

Public Procurement Act may influence the method of securing the related document, which make it to be costly $\mathrm{H}_{5}$ the result from the Table 5 and Figure 5 indicated that $(\beta=0.557 ; \mathrm{T}=11.285, \mathrm{p}<0.005)$ and this support the argument. In the same vain it was hypothesis that securing 
related document may influence the bidding transaction costs for construction due to difficulties and other challenges $\mathrm{H}_{6}(\beta=0.156 ; \mathrm{T}=9.294, \mathrm{p}=0.000)$, this shows that the hypothesis is well supported. But, $\mathrm{H}_{7}$ has shown that procurement guides does not contributed towards bidding transaction costs for construction directly $(\beta=0.198 ; \mathrm{T}=1.060 ; \mathrm{p}=0.289)$ and this result disconfirm the hypothesis earlier stated.

Table 5: Parameter Estimate for final structural model of transaction costs of bidding

\begin{tabular}{|c|c|c|c|c|c|}
\hline Paths & $\beta$ Value & Standard Deviation (STDEV) & $\begin{array}{c}\text { T Statistics } \\
(\mid \beta / \text { STDEV } \mid)\end{array}$ & P Values & Decision \\
\hline $\mathrm{CA} \rightarrow \mathrm{BTCC}$ & 0.243 & 0.123 & 1.976 & 0.021 & SS \\
\hline ED $->$ BTCC & -0.449 & 0.073 & 6.151 & 0.005 & SS \\
\hline $\mathrm{ED}->\mathrm{CA}$ & 0.004 & 0.136 & 0.032 & 0.974 & NS \\
\hline PG -> BTCC & 0.198 & 0.187 & 1.060 & 0.289 & NS \\
\hline PG -> CA & 0.521 & 0.202 & 2.579 & 0.015 & SS \\
\hline PG -> ED & -0.489 & 0.080 & 6.096 & 0.000 & SS \\
\hline PG -> SRD & 0.557 & 0.049 & 11.285 & 0.000 & SS \\
\hline SRD -> BTCC & 0.158 & 0.017 & 9.294 & 0.000 & SS \\
\hline
\end{tabular}

Note: SS=Significant, (T-statistics $>1.96$; -value <0.05) NS=Not Significant

In addition, Table 6 show the result for the models fitness indicating the SRMR, d_G, $\mathrm{d}_{\mathrm{ULS}}$, and the NFI (normal fit index) with their corresponding HI95 percentile bootstrap confidence interval (HI95) based on 999 bootstrap samples and acceptable level for NFI of $>0.9$ (Forze \& Filippini, 1998; Henseler, et al., 2016; Awang, 2014; Ishiyaku et al.,
2016). The geodesic discrepancy (d_G) between the empirical correlation matrix and the implied correlation matrix of the saturated model (i.e. a model in which all constructs are allowed to covary) is ranges between 0.796 to 0.819 and lies below its corresponding HI95 value of 1.104 .

Table 6: Overall Goodness of Fit (GoF) Assessment for the predictive model

\begin{tabular}{l|ccc}
\hline Fit Indices & Saturated Model & Estimated Model & HI95 \\
\hline SRMR & 0.123 & 0.124 & 1.023 \\
d_ULS & 3.193 & 3.206 & 3.410 \\
d_G & 0.796 & 0.819 & 1.104 \\
NFI & 0.988 & 0.977 & $>0.9$ \\
\hline
\end{tabular}

Consequently, the implied correlation matrix does not differ significantly (1 percent level) from the empirical correlation matrix. Also, the SRMR also ranges 0.123 to $0.124<\mathrm{HI} 95$ and NFI >0.9 Table 6. This provides evidence for an acceptable model fit $(\mathrm{Hu}$ and Bentler, 1999). We can thus conclude that the measurement model provides an adequate explanation of the covariation in the data and can be used to predict the linear regression model as shown in equations (4.0-4.3) below.

The structural model Figure 5 depicted the coefficient of determination $\left(R^{2}\right)$ value of 0.270 . This provides information on the amount of BTCC variance explained or predicted by the research exogenous constructs. The model revealed that 27.0 percent of BTCC variance is explained by the research exogenous constructs. In other words, ED, CA SRD, and PG jointly determined, explained or predicted about 27.0 percent of the variance in BTCC.

\section{Model Development}

Using the SmartPLS-SEM (Partial Least SquaresStructural Equation Modeling) three models were developed to predict likely bidding transaction costs for construction projects based on the sources of transaction costs identified (see Table 1).

The following discussion focuses on significant exploratory variables (PPA 2007 sections) that influence sources of transaction costs bidding. Contracting firms and consultants could adopt these BTCC Models, which may help in determining the probable costs of their tendering expenses in a year.

Based on the results therefore, the three constructs of the transaction costs sources are found to be significant in determining bidding transaction costs for construction amongst those contracting firms. Although the application of the transaction costs economic theory in construction industry differs from the environment in which it was applied in previous studies, nevertheless the findings are consistent with Yahaya, Oyediran and Onukwube, 2019b; $\mathrm{Li}$ at al., $(2012,2013)$ concerning sources of transaction costs influence as significant antecedents of the expenses incurred in bidding. Therefore, based on this significance of the construct the models were being derived as follows: 
$\mathrm{CAC}_{1}=\beta_{0}+0.580 * \mathrm{STCCA}_{10}+0.538 * \mathrm{STCCA}_{11}+0.788 * \mathrm{STCCA}_{3}+0.704 * \mathrm{STCCA}_{5}+0.923 * \mathrm{STCCA}_{7}$ (2)

$$
\mathrm{SRD}_{1}=\beta_{0}+0.586 * \mathrm{STCRD}_{1}+0.568 * \mathrm{STCRD}+0.834 * \mathrm{STCRD}_{4}+0.647 \mathrm{STCRD}_{5}
$$

\section{While the overall transaction costs of bidding for contractors is:}

The overall transaction costs model for bidding construction projects based on the result shown in Figure 4.4 and Table 4.21, eligibility documents cost at $(\beta=-0.449, \mathrm{p}<0.005)$, contract administration costs at $(\beta=0.243<0.021)$ and securing required documents at $(\beta=0.158, \mathrm{p}<0.006)$ significantly predict the transaction costs model for bidding.

The overall model BTCC $=\beta_{0}+\beta_{1} *$ EDC $+\beta_{2} *$ SRD $+\beta_{3} *$ CAC $+e$

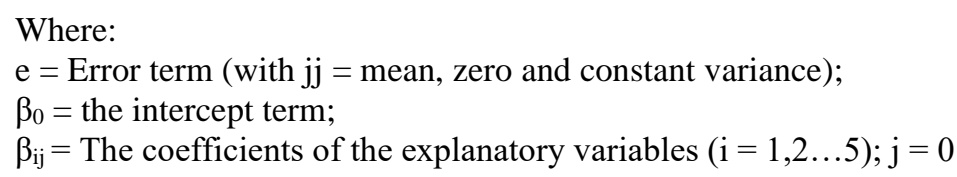

\section{CONCLUSION}

This study is an in-depth analysis in examining factors underlying the expenses of contracting firms in NorthWest, Nigeria. It offers new insights into the understanding of the magnitude of costs incurred by various construction companies when bidding for construction projects in the public sector. Furthermore, the study extends the application of the theory of transaction costs economic in the construction industry area, namely the bidding processes.

The findings show that most of the factors investigated are very significant in determining the magnitude of bidding costs in Nigeria particularly in North-West States. Based on these findings, the contractors, consultants and government or policy makers can provide new relevant strategies for reducing such expenses so as to increase competition and easy of doing construction business in Nigeria. Moreover, the unforeseen factors identified, which determine parts of transaction costs in bidding processes, highlight the percentage of contract value a construction firms will spends as his transaction costs on averagely $8.21 \%$ after validating the model

\section{Implications of the Study}

The purpose of this study is to demonstrate how contracting firms incurred expenses (Transaction Costs) as a result of bidding public sector projects based on the public procurement Act 2007 in used. This highlight the main sources in the Act that influences such costs of bidding like the eligibility documents (ED), contract administration (CA) and securing related document processes (SRD). Through a survey of the construction firms and the subsequent structural equation modeling in SmartPLS, the main sources that lead to bidding expenses are identified.

In this research, eligibility documents required are Pension commission evidence (PENCOM), Industrial training fund (ITF), National social insurance trust fund (NSITF) and financial regulation council (FRCN). With loadings of $0.925,0.837,0.753$ and 0.727 respectively, they are good indicators of eligibility documents (ED).
Construction companies and bidders should not overlook these mandatory elements of bidding because eligibility documents has been shown to significantly influence bidding transaction costs, their probability for winning the bids is solely based on this requirements and a firm should always acquire them before embarking into the bidding processes.

Meanwhile, it is also revealed that Time it takes to negotiate, Interest rate on loan for projects, Cost incurred annually in bidding, Average amount spent in a year and Average No. of public projects bid in a year are important indicators of contract administration (CA), with loadings of $0.788,0.704,0.923,0.580$ and 0.538 respectively. Although, reduction in time of negotiation, rate on interest, less bids document costs and the number of project to be participate will tremendously reduce the cost of administration in contract.

Generally, the result indicated that the procurement Act various sections have significant influence on those sources based on the path relationship. There is high correlation between the procurement Act (PG) and the three sources of the transaction costs in bidding, with $\beta$-value $0.525,0.509$ and 0.557 . Abiding by the procurement law by public sector (Client) through proper selection of procurement method, processing certificate of No Objection from BPP in time, awarding to the lowest evaluated responsive bidder and less compliant from the contracting firms will mitigate the contractors transaction costs. As a result, contractors' can channel their recommendation through the Bureau of Public Procurement (BPP) to the legislative for considering the amendment of the procurement law especially those sections that increases their costs of bidding. This will furthermore reduce the level of abandon projects in public sector due to high costs of the transaction.

The analysis of inner model shows that eligibility documents (ED), contract administration (CA) and securing related documents (SRD) together can only explain $27.0 \%$ of the variance in bidding transaction costs (BTCC).

It is an important finding because it suggests that there are other sources that construction firms should consider when 
exploring bidding transaction costs indicators in future research.

\section{RECOMMENDATION}

Although this study makes significant contributions to the literature and transaction costs theory, its two major limitations could offer directions for future researches in the area. Firstly, the location of the study is confined to North-West, Nigeria which means the findings cannot be generalized to other geopolitical zones in Nigeria that varies in level of competition, construction opportunities and knowledge on procurement laws. It is suggested that future studies could be conducted in the five geopolitical zones in Nigeria, which comprises North-East, NorthCentral, South-West, South-South and South-East. Construction activities in these five zones have distinct knowledge, professional, technology and competition level. It would be interesting to see how this would affect their bidding transaction costs despite the fact that the procurement law is the same in terms of application in public sector. Secondly, the study is based on limited number of explanatory factors. Presently, eligibility document, contract administration, and securing related document process are considered while other factors which could influence bidding transaction costs have not been investigated. Some potential factors such as Equipments, financial capability and professional staff strength could provide new insights into bidding transaction costs incurred for construction projects.

\section{REFERENCES}

[1] Adeyemi, A. Y., \& Kashiwagi, D. T. (2014). Moving Nigeria's Project Procurement System to Best Value: A Prescription. Civil and Environmental Research, 6(11), 136-145.

[2] Adinyira, E., Fugar, F., \& Osei, A. (2011). Underlying Factors for Construction Research Collaboration in Ghana. Paper presented at the Proceeding 6th Built environment conference $31^{\text {st }}$ July- $2^{\text {nd }}$ August, 2011, Johernusbergu South Africa.

[3] Anaman, K. A., \& Osei-Amponsah, C. (2007). Analysis of the causality links between the growth of the construction industry and the growth of the macro-economy in Ghana. Construction Management and Economics, 25(9), 951-961.

4] Awang, Z. (2014). A handbook on structural equation modeling for Academicians and Practitioners: MPWS Rich Resources Bandar baru bangi, Kuala Lampur, Malaysia.

[5] Creswell, J. W., \& Clark, V. L. P. (2017). Designing and conducting mixed methods research: Sage publications india pvt. Ltd. New Delhi, 110 048, India.

[6] Dadzie, J. (2015). Comparative estimation of the impact of transaction cost of traditional and design-build procurement system in public construction works. Unpublished master of science thesis in procurement management, department of building technology, college of art and built environment, Kwame Nkurumah University of Science and Technology, Kumasi, Ghana.

[7] Dalrymple, J., Boxer, L., \& Staples, W. (2006). Procurement and risk management: Cost of tendering: Adding cost without value? Paper presented at the Clients Driving Innovation: Moving Ideas into Practice, Royal Melbourne Institute of Technology, Australia.

[8] Fayomi, I. O. (2013). Public procurement and due process policy in Nigeria: Thrust, prospects and challenges. Peak Journal of Social Sciences and Humanities, 1(4), 39-45.

[9] Fornell, C., \& Larcker, D. F. (1981a). Evaluating structural equation models with unobservable variables and measurement error. Journal of Marketing Research, 18(1), 39-50.

[10] Golafshani, N. (2003). Understanding reliability and validity in qualitative research. The qualitative report, 8(4), 597-607.
[11] Gupta, V. (2009). Application of low-cost adsorbents for dye removal-a review. Journal of environmental management, 90(8), 2313-2342.

[12] Hair Jr, J. F., Sarstedt, M., Hopkins, L., \& Kuppelwieser, V. G. (2014a). Partial least squares structural equation modeling (PLS-SEM). European Business Review, 25(2), 106-121.

[13] Hair, J. F., Gabriel, M., \& Patel, V. (2014b). AMOS covariance-based structural equation modeling (CB-SEM): Guidelines on its application as a marketing research tool. Brazilian Journal of Marketing, 13(2), 654-695.

[14] Hair, J. F., Money, A. H., Samouel, P., \& Page, M. (2007). Research methods for business. Education and Training.

[15] Hair, J. F., Sarstedt, M., Ringle, C. M., \& Mena, J. A. (2012) An assessment of the use of partial least squares structura equation modeling in marketing research. Journal of the Academy of Marketing Science, 40(3), 414-433.

[16] Henseler, J., Hubona, G., \& Ray, P. A. (2016). Using PLS path modeling in new technology research: updated guidelines. Industrial Management and Data Systems, 116(1), 2-20.

[17] Henseler, J., Ringle, C. M., \&d Sinkovics, R. R. (2009). The use of partial least squares path modeling in international marketing New challenges to international marketing (pp. 277 319): Emerald Group Publishing Limited.

[18] Hosseini, R., Chileshe, N., Zou, J., \& Baroudi, B. (2012) Approaches of implementing ICT technologies within the construction industry. Australasian Journal of Construction Economics and Building-Conference Series, 1(2), 1-12.

[19] Hu, L. T., \& Bentler, P. M. (1998). Fit indices in covariance structure modeling: Sensitivity to underparameterized model misspecification. Psychological Methods, 3(4), 424.

[20] Ishiyaku, B., Kasim, R., \& Harir, A. (2016b). Confirmatory factoral validity of public housing performance evaluation constructs. Journal of Building Performance, 7(1), 35-67.

[21] Ishiyaku, M. B. (2017). Comparative Analysis of SMEs and GDP in Ghana and Nigeria: American University of Nigeria.

[22] Jibrin, M. S., Ejura, S. B., \& Augustine, N. I. (2014). The public procurement reforms in Nigeria: Implementation and compliance challenges. Journal of Asian Business Strategy, 4(11), 149-171

[23] Lowry, P. B., \& Gaskin, J. (2014). Partial least squares (PLS) structural equation modeling (SEM) for building and testing behavioral causal theory: When to choose it and how to use it. IEEE transactions on professional communication, 57(2), 123146.

[24] Lynn, P., Erens, B., \& Sturgis, P. (2012). A strategy for survey methods research in the UK. London, England: ESRC Survey Resources Network.

[25] National Bureau of Statistics (2015). Nigerian Government Report

[26] Oladirin, O. T., Olatunji, S. O., \& Hamza, B. T. (2013). Effect of selected procurement systems on building project performance in Nigeria. International journal of sustainable construction engineering and technology, 4(1), 48-62.

[27] Omagobon, P. (2016). An Assessment of Compliance with the Public Procurement Act by Nigerian Local Government. Journal of Accounting and Financial Management, 2(4), 1-11.

[28] Onyema, E. (2011). Challenges and prospects of public procurement practice in Nigeria: An analysis. Nigeriaworld, Retrieved online on $5^{\text {th }}$ April, 2017.

[29] Osman,F., A. \& Muhammed, O., M. (2017). Measuring a cash waqf giving behavior Among muslim donors in malaysia: a Theory of planned behavior approach Using structural equation modeling. JIMFIR 14(2), 39-63.

[30] Oyeyipo, O., Odusami, K. T., Ojelabi, R. A., \& Afolabi, A. O. (2016). Factors Affecting Contractors' Bidding Decisions for Construction Projects in Nigeria. Journal of construction in developing countries, 21(2), 21-35.

31] Pavel, J., \& Vítek, L. (2012). Transaction costs of environmental taxation: the administrative burden Handbook of Research on Environmental Taxation: Edward Elgar Publishing.

[32] Rahman, I. A., Memon, A. H., Aziz, A. A. A., \& Abdullah, N H. (2013). Modeling causes of cost overrun in large construction projects with partial least square-SEM approach: 
contractor's perspective. Research Journal of Applied Sciences, Engineering and Technology, 5(06), 1963-1972.

[33] Rajeh, M. (2014). Impact of procurement systems on transaction costs: A structural equation modeling methodology. Proceedings of the 4th New Zealand Built Environment Research Symposium (NZBERS). Auckland,New Zealand. Accessed $15^{\text {th }}$ September 2018.

[34] Ramayah, T., Lee, J. W. C., \& In, J. B. C. (2011). Network collaboration and performance in the tourism sector. Service Business, 5(4), 411.

[35] Sarfo, P. A., \& Mintah, R. (2013). Assessing the Effect of the Procurement Act (663) on the Public Financial Management in Ashanti Region. American Journal of Rural Development, 1(4), 91-98.

[36] Shwarka, S. M., \& Anigbogu, N. A. (2012, September). Impact of the Public Procurement Reform on public building projects delivery in Nigeria. In Proceedings 28th Annual ARCOM Conference (pp. 969-977).

[37] Tominiyi, O., Wolemi, E., Ibi, O., \& Jonathan, A. (2015). Construction and projects in Nigeria: Overview. Practical Law Multi-Jurisdictional guide 2014/2015

[38] Voordijk, H., de Haan, J. \& Joosten, G.-J. (2000). Changing Governance of Supply Chains in the Building Industry: A Multiple Case Study. European Journal of Purchasing \& Supply Management, 6 (3-4), 217-225.

[39] Winch, G. (1996). Contracting Systems in the European Construction Industry: A Sectoral Approach to the Dynamics of Business Systems. In Kristensen, R. W. A. P. H. (Ed.) The Changing European Firm: Limits to Convergence. London, Routledge.

[40] Yahaya, M., Oyediran, O., \& Onukuwbe, H. (2019b). Evaluating Factors Affecting Transaction Costs of Contractors in Public Procurement in Nigeria: PLS-SEM Approach. FUTY Journal of the Environment, 13(1), 46-64.

[41] Yahaya., M.L., Oyediran., O.S., and Onukwube., H.N (2019a). Challenges of PPA 2007 in the implementation of government policies related to the construction industry. Journal of Civil and Construction Engineering, 5(3), 26-40.

[42] Yin, R. K. (2003). Case study research: design and methods,(3rd) Sage Publications. Thousand Oaks, California. 